(2) Open Access Full Text Article

\title{
Higher vitamin D levels may be associated with higher levels of sunlight exposure and higher intake of vitamin $D$ by diet
}

This article was published in the following Dove Press journal:

Clinical Interventions in Aging

17 August 2016

Number of times this article has been viewed

\section{Sevilay Muratli \\ Fatih Tufan \\ Gulistan Bahat \\ Mehmet Akif Karan \\ Department of Geriatrics, Istanbul Faculty of Medicine, Istanbul University, Istanbul, Turkey}

Correspondence: Fatih Tufan

Department of Geriatrics, Istanbul Faculty of Medicine, Istanbul University, PB 34093, TurgutOzal Street, Sehremini, Fatih, Istanbul, Turkey Tel +902124141500

$\mathrm{Fax}+902124142022$

Email drfatiht@istanbul.edu.tr

\section{Dear editor}

We read the article by Al-Eisa et $\mathrm{al}^{1}$ entitled "Correlation between vitamin D levels and muscle fatigue risk factors based on physical activity in healthy older adults," regarding an important subject - the association among vitamin D deficiency, physical activity, and muscle fatigue; the findings of this study indicate that increased physical activity is associated with higher vitamin D levels and less fatigue. We would like to comment on this well-designed and performed study.

In this study, significantly higher levels of vitamin D concentrations were reported in physically active participants compared with those with lower physical activity. However, there were no data on sunlight exposure or the seasons in which the study was conducted. Physically active participants may have higher exposure to sunlight compared with those with lower physical activity. Furthermore, subjects with higher physical activity may have a healthier diet behavior, which means they may have higher vitamin $\mathrm{D}$ intake by diet. If these data are not available, it is better to mention this as a limitation of the study.

Second, the authors stated that they evaluated fatigue using the visual analog scale (VAS) as well. However, the "Methods" section indicates that VAS was used to assess pain. The authors should clearly mention if VAS was used to assess pain, fatigue, or both.

Finally, the mean total and free calcium levels seem to be erroneously reported. In particular, physically active subjects seem to have severe hypercalcemia when their total and free calcium levels in Table 2 are taken into account.

\section{Disclosure}

The authors report no conflicts of interest in this communication.

\section{Reference}

1. Al-Eisa ES, Alghadir AH, Gabr SA. Correlation between vitamin D levels and muscle fatigue risk factors based on physical activity in healthy older adults. Clin Interv Aging. 2016;11:513-522. 


\section{Authors' response}

Einas S Al-Eisa'

Ahmad H Alghadir'

Sami A Gabri,2

'Rehabilitation Research Chair, College of Applied Medical Sciences, King Saud University, Riyadh, Kingdom of Saudi Arabia; ${ }^{2}$ Department of Anatomy, Faculty of Medicine, Mansoura University, Mansoura, Egypt

Correspondence: Sami A Gabr

Rehabilitation Research Chair (RRC), College of Applied Medical

Sciences, King Saud University, PO Box 10219 Riyadh II433,

Kingdom of Saudi Arabia

Tel +966 I 562060018

$\mathrm{Fax}+966$ । 469854 I

Email nadalab2009@hotmail.com; drGabr14@yahoo.com;

sgabr@ksu.edu.sa

\section{Dear editor}

We would like to thank Muratli et al for their comments on our study. First, in our study "Correlation between vitamin D levels and muscle fatigue risk factors based on physical activity in healthy older adults," the participants were indoor residents and if they go out they were fully dressed, without sun exposure to the skin. However, the effect of sun exposure along with physical activity was also studied in another group and the data are under publication process.

Also, we mentioned in our study that participants who were taking calcium, vitamin $\mathrm{D}$, or multivitamin supplements, which may affect the data, were excluded from the study. The participants were instructed not to change their normal eating habits during the entire period of data collection. ${ }^{1}$

Second, regarding the visual analog scale (VAS) as a measure for the assessment of fatigue, although many research studies ${ }^{2-4}$ reported VAS score as a measure in muscle fatigue, we performed muscle biochemical markers, such as creatine kinase, hydroxyproline, and troponin I, which along with lactic acid dehydrogenase activity generally allow earlier detection of muscle injury, especially muscle soreness following training interventions..$^{5-11}$ These markers supported the measurements of VAS score and nullified the confusion about the assessment of fatigue by VAS in our study.

Finally, in our study, the mean total and free calcium levels were presented in $\mathrm{mmol} / \mathrm{L}$ as shown in Table 2; the normal range values are $2.2-2.6 \mathrm{mmol} / \mathrm{L}$ for total calcium and $1.05-1.3 \mathrm{mmol} / \mathrm{L}$ for free ionized calcium. ${ }^{12,13}$ In this case, the data of both the moderate and physically active participants in our study were not severe hypercalcemia as suggested.

\section{Disclosure}

The authors report no conflicts of interest in this communication.

\section{References}

1. Al-Eisa ES, Alghadir AH, Gabr SA. Correlation between vitamin D levels and muscle fatigue risk factors based on physical activity in healthy older adults. Clin Interv Aging. 2016;11:513-522.

2. Nunes GS, Bender PU, de Menezes FS, Yamashitafuji I, Vargas VZ, Wageck B. Massage therapy decreases pain and perceived fatigue after long-distance Ironman triathlon: a randomised trial. J Physiother. 2016;62(2):83-87.

3. Hewlett S, Dures E, Almeida C. Measures of fatigue: Bristol Rheumatoid Arthritis Fatigue Multi-Dimensional Questionnaire (BRAF MDQ), Bristol Rheumatoid Arthritis Fatigue Numerical Rating Scales (BRAF NRS) for severity, effect, and coping, Chalder Fatigue Questionnaire (CFQ), Checklist Individual Strength (CIS20R and CIS8R), Fatigue Severity Scale (FSS), Functional Assessment Chronic Illness Therapy (Fatigue) (FACIT-F), Multi-Dimensional Assessment of Fatigue (MAF), Multi-Dimensional Fatigue Inventory (MFI), Pediatric Quality Of Life (PedsQL) Multi-Dimensional Fatigue Scale, Profile of Fatigue (ProF), Short Form 36 Vitality Subscale (SF-36 VT), and Visual Analog Scales (VAS). Arthritis Care Res (Hoboken). 2011;63(Suppl 11): S263-S286.

4. Hewlett S, Hehir M, Kirwan JR. Measuring fatigue in rheumatoid arthritis: a systematic review of scales in use. Arthritis Rheum. 2007;57(3): 429-439.

5. van der Wielen RP, Löwik MR, van der Berg H, et al. Serum vitamin D concentrations among elderly people in Europe. Lancet. 1995;346(8969):201-210.

6. Oh JH, Kim SH, Kim JH, Shin YH, Yoon JP, Oh CH. The level of vitamin $\mathrm{D}$ in the serum correlates with fatty degeneration of the muscles of the rotator cuff. J Bone Joint Surg Br. 2009;91(12):1587-1593.

7. Rodenburg JB, Bär PR, De Boer RW. Relations between muscle soreness and biochemical and functional outcomes of eccentric exercise. J Appl Physiol (1985). 1993;74(6):2976-2983.

8. Siegel AJ, Januzzi J, Sluss P, et al. Cardiac biomarkers, electrolytes, and other analytes in collapsed marathon runners: implications for the evaluation of runners following competition. Am J Clin Pathol. 2008;129(6):948-951.

9. Schuback K, Essén-Gustavsson B, Persson SG. Incremental treadmill exercise until onset of fatigue and its relationship to metabolic response and locomotion pattern. Equine Vet J Suppl. 1999;30:337-341.

10. Fridén J, Seger J, Ekblom B. Sublethal muscle fiber injuries after high-tension anaerobic exercise. Eur J Appl Physiol Occup Physiol. 1988;57(3):360-368.

11. Shave R, Ross P, Low D, George K, Gaze D. Cardiac troponin I is released following high-intensity short-duration exercise in healthy humans. Int J Cardiol. 2010;145(2):337-339.

12. Council for Continuing Pharmceutical Education. Tables of normal values. Available from: http://www.ccpe-cfpc.com/en/pdf_files/drug_lists/ normal_values.pdf. Accessed July 19, 2016.

13. Jafri L, Khan AH, Azeem S. Ionized calcium measurement in serum and plasma by ion selective electrodes: comparison of measured and calculated parameters. Indian J Clin Biochem. 2014;29(3):327-332. 
Dove Medical Press encourages responsible, free and frank academic debate. The content of the Clinical Interventions in Aging 'letters to the editor' section does not necessarily represent the views of Dove Medical Press, its officers, agents, employees, related entities or the Clinical Interventions in Aging editors. While all reasonable steps have been taken to confirm the content of each letter, Dove Medical Press accepts no liability in respect of the content of any letter, nor is it responsible for the content and accuracy of any letter to the editor.

Clinical Interventions in Aging

\section{Publish your work in this journal}

Clinical Interventions in Aging is an international, peer-reviewed journal focusing on evidence-based reports on the value or lack thereof of treatments intended to prevent or delay the onset of maladaptive correlates of aging in human beings. This journal is indexed on PubMed Central, MedLine,

CAS, Scopus and the Elsevier Bibliographic databases. The manuscrip management system is completely online and includes a very quick and fair peer-review system, which is all easy to use. Visit http://www.dovepress. com/testimonials.php to read real quotes from published authors.

Submit your manuscript here: http://www.dovepress.com/clinical-interventions-in-aging-journal 